\title{
Providing Education for a Mother in Stunting Prevention: A Collaborative Study through Action Research
}

\author{
Dewi Dolifah $^{1, *}$, Diding Kelana Setiadi ${ }^{1}$, Delli Yuliana Rahmat ${ }^{1}$, Tedi Supriyadi $^{2}$ \\ ${ }^{1}$ Nursing Study Program, Universitas Pendidikan Indonesia, Sumedang, West Java, Indonesia \\ ${ }^{2}$ Physical Education Primary School Teacher Education Study Program, Universitas Pendidikan Indonesia, Sumedang, West Java, \\ Indonesia
}

Received November 23, 2020; Revised January 12, 2021; Accepted April 22, 2021

\section{Cite this paper in the following citation styles}

(a): [1] Dewi Dolifah, Diding Kelana Setiadi, Delli Yuliana Rahmat, Tedi Supriyadi, "Providing Education for a Mother in Stunting Prevention: A Collaborative Study through Action Research," Universal Journal of Public Health, Vol. 9, No. 2, pp. 83 - 93, 2021. DOI: 10.13189/ujph.2021.090207.

(b): Dewi Dolifah, Diding Kelana Setiadi, Delli Yuliana Rahmat, Tedi Supriyadi (2021). Providing Education for a Mother in Stunting Prevention: A Collaborative Study through Action Research. Universal Journal of Public Health, 9(2), 83 - 93. DOI: 10.13189/ujph.2021.090207.

Copyright $\bigcirc 2021$ by authors, all rights reserved. Authors agree that this article remains permanently open access under the terms of the Creative Commons Attribution License 4.0 International License

\begin{abstract}
One of the attempts to prevent stunting requires the implementation of new intervention, especially in upgrading a mother's education. A mother's substandard education is a vital risk factor in child growth. Therefore, this study aims to educate mothers in terms of improving a mother's understanding of stunting prevention through Bina Keluarga Balita (helping family with toddler) program as part of the Kampung Keluarga Berencana (family planning village) program initiated by the government. Action research method was employed as the design of this study by involving 100 mothers of toddlers as research participants. This study was conducted in one of the areas in Sumedang - West Java that carried out the Kampung Keluarga Berencana program. This study resulted in several findings, including: 1) Mothers lack education concerning stunting issue; 2) The need for parenting intervention related to toddler's nutritional intake; and 3) There are 5 steps abbreviated to I-CARE, serving as the framework to educate mothers regarding stunting prevention. Through this model, this study showed a rise in mothers' insights and understanding regarding stunting prevention efforts. Hence, it can be concluded that the I-CARE model comprises reflective and solution steps that can be implemented to educate mothers regarding stunting prevention and government program succession efforts through Kampung KB program.
\end{abstract}

Keywords Stunting, Action Research, Bina Keluarga Balita, Kampung Keluarga Berencana

\section{Introduction}

Failure of linear growth is globally the most common form of malnutrition [1]. With estimated 165 million toddlers suffering from stunting [2], stunting has been identified as a top public health priority, and there are ambitious targets to reduce the prevalence of stunting by $40 \%$ in between 2010 and 2025 [3]. WHO sets a limit of tolerance for stunting (short stature) to a maximum of $20 \%$ or one-fifth of the total number of toddlers [4]-[6]. Meanwhile, the prevalence of child stunting in Indonesia had remained high over the past decade, which was nationally around $37 \%$ [7]. Stunting issue in Indonesia was ranked the fifth in the world for the number of children with stunting [8]. The national prevalence of stunting reached $37.2 \%$, among whom $18 \%$ were very short and $19.2 \%$ short, indicating a rise from $2010(35.6 \%)$. It was recorded that 7.8 million out of 23 million toddlers were stunted in growth, $18.5 \%$ were categorized as 'very short' and $17.1 \%$ were categorized as 'short'[9]. This was also what made WHO classifies Indonesia as a country with 
poor nutrition status [10].

In the National Medium-Term Development Plan (RPJMN, Rencana Pembangunan Jangka Menengah Nasional), the Indonesian government targeted a decrease in stunting prevalence from the initial status of $32.9 \%$ to $28 \%$ in 2019 [9]. To reduce the stunting rate, the government had also designated 100 priority districts to be managed at the first stage, and then followed by 200 more districts [9]. One of the government's definite attempts at reducing the stunting rate down to the grassroots was by the introduction of Bina Keluarga Balita (helping family with toddler) program (hereinafter abbreviated BKB) as one of the programs listed under the Kampung Keluarga Berencana/Family Planning Village (hereinafter abbreviated Kampung KB) program in family security and family empowerment (family development) actions. BKB aims at improving parents' understanding and skills in nurturing toddlers [11]-[13].

Several studies related to stunting have been carried out in various countries, for example, a study by De Onis et al. (2012) summarized the progress made in the last two decades and helped identify areas that need effective interventions. They measured stunting prevalence and trends in children using WHO's growth standard. Their study concluded that there was an overall decline in developing countries, but stunting remained a major public health problem in many of these countries [14]. A study conducted by Yasmin et al. (2014) postulated that stunting had correlations with several variables, namely low household expenditure, low Healthy Eating Index scores, short maternal height, low maternal education, high number of family members, low energy and protein adequacy levels, older age, living in rural areas, male gender, low sanitation score and higher levels of phosphorus and vitamin C adequacy [15]. A study by Aryastami et al. (2017) analyzed the correlation between low birth weight (LBW), child feeding practices and neonatal disease with stunting in Indonesian toddlers, resulting in a conclusion that low birth weight (LBW), gender (male), with a history of neonatal disease complemented by poverty were factors associated with stunting in children aged 12-23 months in Indonesia, with LBW as the main stunting determinant [16].

In comparison with the previous studies, this study is motivated by a lack of a mother's understanding in attempt to prevent stunting. Therefore, this study aims at increasing a mother's understanding and insight to prevent stunting. This is offered as a real initiative to appreciate the Indonesian government's program in an effort to decrease stunting rates by involving public participation in Kampung KB through the program of Bina Keluarga Balita. Therefore, this study focuses on finding practical steps to educate the public in preventing stunting through the program of Bina Keluarga Balita.

\section{Theoretical Framework}

Stunting in toddlers is very common in Indonesia as a result of malnutrition, and it is closely related to internal (maternal health) and external factors such as feeding practices, diseases and the socio-economic conditions of society [16]. Stunting is also linked to higher rate of degenerative diseases that emerge with age [17]. Moreover, in developing countries such as Indonesia, it was still fluctuating from 2007 to 2017. The prevalence of stunting in toddlers in Indonesia was $36.8 \%$ in $2007,35.6 \%$ in 2010 , $37.3 \%$ in 2013 , and $29.6 \%$ in 2017 [18], and the stunting rate in 2018 was still high at $30.8 \%$ [19], [20]. Growth failure often begins in the womb and proceeds for at least the first 2 years of postnatal life [21]. Studies show that stunting is associated with malnutrition, particularly with a plant-based diet [22].

Early childhood stunting results in poor cognitive, motor, and socio-emotional development [23] and increased mortality [24]-[26]. Children with stunting who do not reach the potential of their full growth will experience delayed growth into adolescence and adulthood [27]. The functional consequences of stunting persisted into adulthood are indicated by a lack of work capacity [28]. Meanwhile, women have a significant risk of death during childbirth [29] and adverse birth outcomes [30], [31].

Understanding the factors that bring about stunting and understanding the impact caused by stunting can lead to making the right policies and eliminating socio-economic inequality, considering that inequality can lead to stunting [32]. One of the attempts to prevent stunting requires the implementation of new interventions, especially in upgrading mother's education [32] [27]. Substandard maternal education is a vital risk factor for child growth [26].

One of the government's definite attempts at reducing the stunting rate down to the grassroots was the introduction of BKB as one of the programs listed under the Kampung KB program in family security and family empowerment (family development) actions [33]-[35]. BKB aims at improving parents' understanding and skills in nurturing toddlers [33].

Kampung KB is essentially an implementation of a family-based mental revolution adjusted to local wisdom [36]. It is a miniature of integrated and comprehensive implementation of family planning program at the level of field lines (village/sub-district/hamlet/community units (RW, Rukun Warga)). The concept of Kampung KB is an integrated concept of the Family Planning (KB, Keluarga Berencana) program with other development programs, such as education, health, economy [37]. Kampung KB is designed as an effort to empower the community towards the management of the KB program. Its activities are managed based on the principles of 'by and for the community' [38]. 
Generally, the objective of introducing Kampung KB program is to improve the life quality of the community at village level or equivalent through population programs, $\mathrm{KB}$ and family development as well as related sector development in order to establish quality small families [36], [38]. The implementation of Kampung KB includes: 1) population; 2) family planning and reproductive health; 3) family security and family empowerment (family development); and 4) cross-sectoral activities such as housing, socio-economy, health, women's empowerment, and child protection - tailored to the needs of the Kampung $\mathrm{KB}$ area [39].

\section{Method}

\subsection{Design}

Action research design is suitable for this study because it provides an opportunity for researchers to find new efforts in accordance with conditions and needs [40], in this case efforts to prevent stunting. Through action research, researchers seek to explore practical problems in order to find solutions [41]. Researchers examined problems related to stunting through the optimization of $\mathrm{BKB}$ program.

This study employs three procedural steps, namely pre-action analysis, action implementation, and post-action analysis. The first step is conducted by analyzing stunting problems and determinants. The results of this step become a reference for formulating action steps that need to be formulated in the next step. The second step is the implementation of the action formula to be given. The third step is a form of evaluation activities of all the action steps given to observe the success of the action given. The procedure of these steps is depicted in Figure 1.

\subsection{Collaboration Aspects}

Moreover, in conducting this activity, researchers use collaboration principles as a characteristic of action research design [42]. Collaboration in this study, apart from researchers being practitioners in the field of public health, also involved academics in the field of education in general and health education in particular, as well as divisions of local government, namely the related public health offices. Subsequently, the researchers also collaborated with one of the student activity units at one of the campuses in Sumedang district. Studies employing collaborative action research processes in education involve collaboration between teachers, or between teachers and researchers [43], [44].

To initiate collaboration, the researchers refer to the method employed by Heil [45], specifically announcing what needed in this project and anyone interested in this project. At the time this project was announced, there were four people who were interested in being involved in this study, namely one colleague with a qualification of child nursing, one person specializes in the field of public health, and one person in the field of general and character education. These qualifications constitute a reliable collaboration providing that the main focus of this study is to provide education and advocacy for the community as an attempt to prevent stunting.

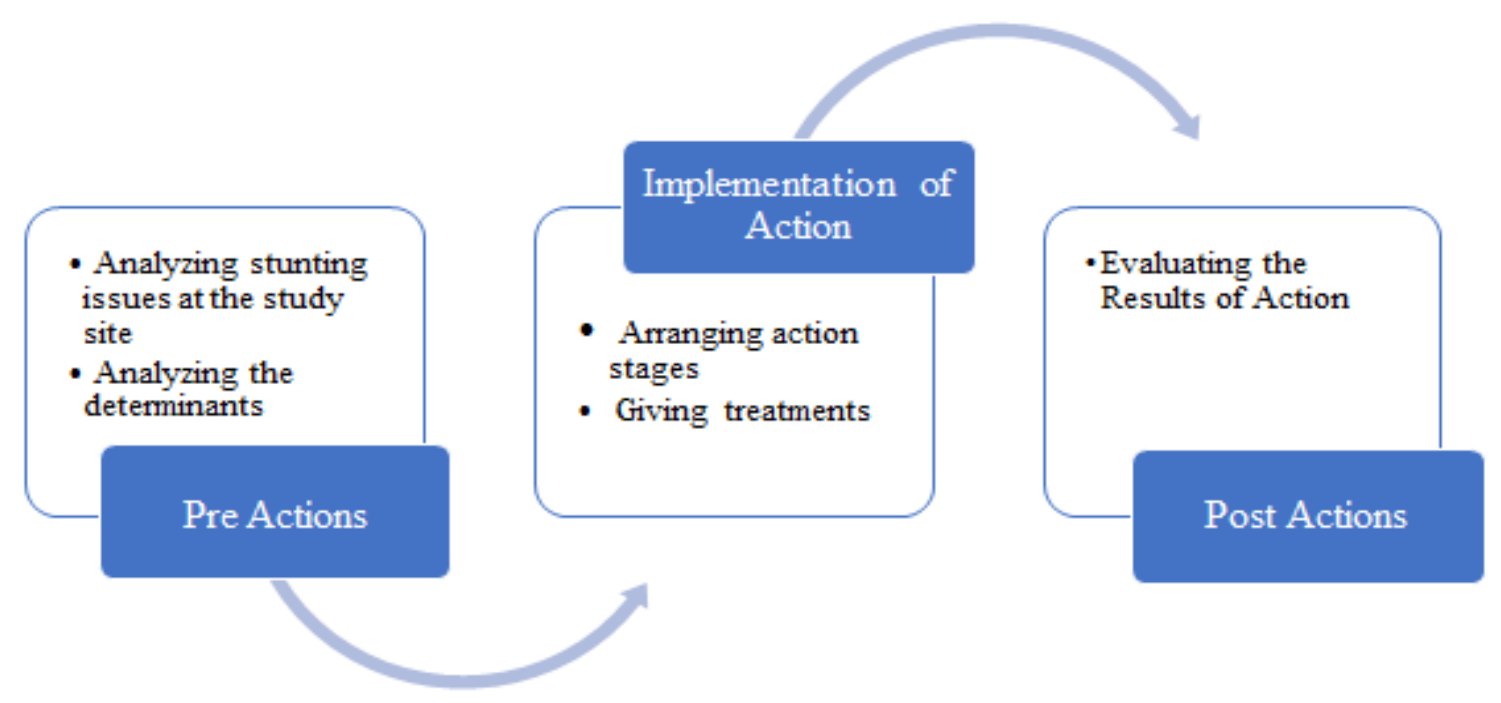

Figure 1. Research Procedures 


\subsection{Site and Participants of the Study}

This study was conducted in one of the pilot areas of Kampung KB program in Dusun 1 Desa Citimun, Sumedang District, West Java. The participants in this study were determined based on several criteria, namely (1) the families registered as the members of Bina Keluarga Balita as many as 247 families, (2) the families who have just had one toddler or are pregnant with their first child, (3) a mother's education level ranging from primary school to senior high school graduates, and (4) those who filled out the survey and show a willingness to be involved as research participants. Based on these criteria, 100 mothers were eligible to participate in this study. The average age of the participants is 30 to 35 years old with various levels of education, in which 72 participants were junior high school graduates and 28 participants were high school graduates.

\subsection{Data Collection and Analysis}

In this study, data were collected in several ways: 1) survey, 2) observation, done to observe the process of Kampung KB activities in the site, and (3) semi-structured interviews to explore opinions regarding stunting. When conducting a survey, Google Document was utilized using Likert and Guttman scale [46], [47] since Google Docs is a profitable and easy-to-use survey tool [46]-[51]. To sum up, the instruments of this study consist of observation guidelines, interview guidelines, and questionnaires.

\section{Findings and Discussion}

To support the findings of this study, a number of steps were undertaken in carrying out research activities. These steps are abbreviated as I-CARE, namely Identification, Consolidation, Action, Review and Evaluation. These I-CARE steps were then combined into abovementioned three study procedures-Identification and Consolidation as Pre-Actions, Action and Review as Implementations of Action, and finally Evaluation as Post-Action to evaluate the given series of actions.

\subsection{Identification-Socialization Stage}

At this stage, the team examined stunting issues in Sumedang, West Java, as the Kampung KB. In mapping the problems, participants' information was obtained, particularly the ones related to: 1) Insights concerning stunting and its prevention; 2) Motivation for stunting prevention; and 3) Perceptions on the role of BKB in stunting prevention education. To collect this information, a survey involving 100 participants was conducted. The survey was conducted using two scales developed by Louis Guttman called the Guttman scale [47], and a scale developed by Rensis Likert called the Likert scale [46]. The survey results are presented in Table 1-6 below:
Table 1. Experience of Active Participation in Stunting Prevention

\begin{tabular}{|c|c|c|}
\hline Learning Experiences & Yes & No \\
\hline Have you heard of the term 'stunting'? & 14 & 86 \\
\hline $\begin{array}{c}\text { Have you received any counseling on stunting } \\
\text { prevention? }\end{array}$ & 6 & 96 \\
\hline
\end{tabular}

As presented in the Table 1, only 14 (14\%) participants in the community were already familiar with the term 'stunting' and $86(86 \%)$ participants were not. Furthermore, a total of $6(6 \%)$ of the participants had received counseling on stunting prevention and 94 (94\%) participants stated that they had never received or attended counseling. Regarding respondents who stated that they had received counseling on stunting prevention. Semi-structured interviews were conducted by asking the questions "where did you get information?" The six participants replied "from other areas". Following observations on the six participants, it was found out that they were newcomers or new residents living in Sumedang District. From this information it can be inferred that the majority of participants had never received education concerning stunting optimally. With this information, the researchers tried to explore the extent of the participants' insights regarding stunting. The survey result is presented in Table 2 below:

Table 2. Community Insights on Stunting

\begin{tabular}{|c|c|c|}
\hline Insights & Yes & No \\
\hline Do you know what stunting is? & 4 & 96 \\
\hline Do you know the factors that cause stunting? & 3 & 97 \\
\hline Do you know how to prevent stunting? & 3 & 97 \\
\hline $\begin{array}{c}\text { Do you know that stunting is a big problem in } \\
\text { Indonesia? }\end{array}$ & 1 & 99 \\
\hline
\end{tabular}

As presented in the Table 2, it was obtained that the public's insights about stunting and how to prevent stunting was very limited. This can be inferred from the participants' answers in recognizing the term 'stunting', there were only 4 (4\%) participants stated they knew, while 96 (96\%) participants stated they did not know the term. A total of 97 (97\%) participants stated that they did not know the factors that caused stunting in children. A total of 97 (97\%) participants did not know how to prevent stunting and 99 (99\%) participants in the community stated that they did not know that stunting is a big problem in Indonesia. However, based on WHO data as reported by Republika (2018), 7.8 million of 23 million children under five years of age in Indonesia suffered from stunting or around 35.6\%, while WHO stated that the tolerance limit for the stunting rate is $20 \%$ of the total number of children under five years old [6]. Referring to the tolerance limit from the WHO, the stunting rate in one of the villages in Sumedang district exceeded $36 \%$, which was 36 out of 100 toddlers aged $0-2$ years were indicated stunting.

From the aforementioned data, information related to the participants' motivation in understanding and preventing stunting was collected. To obtain this information, a survey 
involving 100 participants was conducted. The survey results are presented in Table 3 .

As presented in Table 3, it was found that the majority of the participants had high motivation to recognize and understand stunting. Therefore, the motivation that the participants already have needs to be facilitated considering the findings from Tables 1 and 2, that the participants had very limited information related to stunting as a result of the lack of education. This fact consolidated the presumption that the role of BKB as a government program in the Kampung KB, Sumedang District, West Java, was not running optimally.

\subsection{Consolidation Stage}

To confirm our presumption regarding the role of the BKB in the Kampung KB, we conducted a consolidation with related parties, in this case the BKB cadres in the Kampung KB, the Village Head and the Community Health Center (Puskesmas, Pusat Kesehatan Masyarakat), to communicate the problems found in the previous stage.

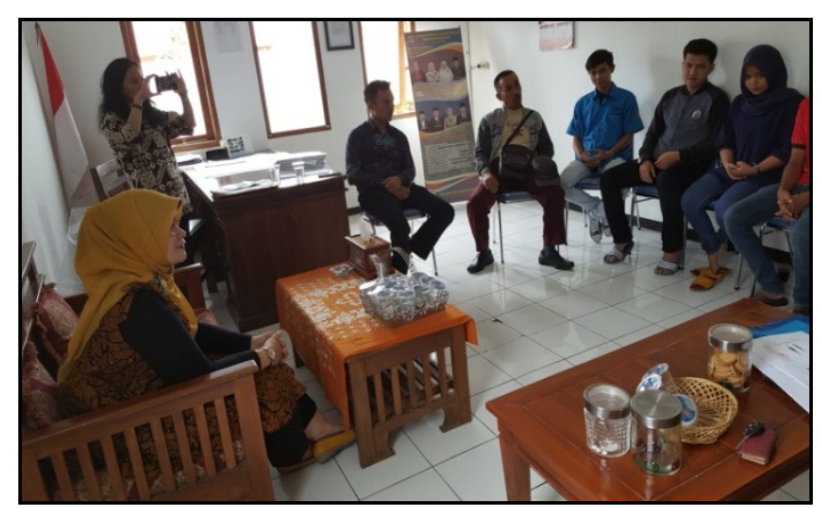

Figure 2. Consolidation situation at the Village Hall

This stage was carried out as an attempt to initiate cooperation in the implementation of research activities and to explore input regarding the actions to be given so that this study activities could run well and were right on target. Regarding the role of BKB, a survey involving 10 $\mathrm{BKB}$ cadres was conducted, in which the result is presented in Table 4.

From the Table 4, it was found that the role of BKB in educating the community was always carried out on a regular basis. The BKB material has led to the prevention of stunting, as stated by 9 cadres. However, providing education about the dangers of stunting through posters had not yet been implemented. The role of BKB, based on the cadres' statements, was to always provide stunting-related services for the residents. This information was actually in contrast with what we obtained from the research participants. However, we took into account what the majority of the participants felt and understood because both cadres and participants' responses were purely confessional.

Subsequently, semi-structured interviews with cadres regarding the counselling materials were conducted. From the interviews, it was found that the counselling material had led to efforts to stunting prevention by providing motivational materials encouraging exclusive breastfeeding with the exclusive breastfeeding movement campaign, materials on complementary feeding, nutrition intake for toddlers and parenting are efforts to prevent stunting.

From the information obtained, another question emerged because the information obtained from the cadres was in contrast with the data collected from the participants, including the high rate of stunting cases in the said region. This prompted the team to collect information from the cadres about BKB institutional management in the Kampung KB by asking a number of questions in form of a survey. The survey result is presented in Table 5 .

Table 3. Motivation of the Community

\begin{tabular}{|c|c|c|c|c|c|}
\hline Statements & $\begin{array}{l}\text { Strongly } \\
\text { Disagree }\end{array}$ & Disagree & $\begin{array}{l}\text { Unable to } \\
\text { Judge }\end{array}$ & Agree & $\begin{array}{c}\text { Strongly } \\
\text { Agree }\end{array}$ \\
\hline & 0 & 0 & 0 & 64 & 36 \\
\hline \multicolumn{6}{|l|}{$\begin{array}{l}\text { Every family who has a toddler, especially a mother, is very } \\
\text { important to have insights regarding stunting } \\
\text { Every family who has a toddler, especially a mother, needs to } \\
\text { understand the factors that cause stunting }\end{array}$} \\
\hline & 0 & 0 & 0 & 78 & 22 \\
\hline $\begin{array}{l}\text { Every family who has a toddler, especially a mother, needs to } \\
\text { understand the efforts to prevent stunting }\end{array}$ & 0 & 0 & 3 & 82 & 15 \\
\hline
\end{tabular}

Table 4. The Roles of BKB in Stunting Prevention

\begin{tabular}{|c|c|c|}
\hline Questions & Yes & No \\
\hline Are BKB activities carried out on a regular basis? & 9 & 1 \\
\hline Do BKB materials lead to stunting prevention? & 9 & 1 \\
\hline Does BKB provide education to residents through posters about the dangers of stunting? & & 10 \\
\hline Do BKB cadres provide consultation services on stunting to residents? & 10 & \\
\hline
\end{tabular}


Table 5. Institutional Management of BKB

\begin{tabular}{|c|c|c|}
\hline Questions & Yes & No \\
\hline Are there BKB Groups in every RW? & 0 & 10 \\
\hline Is the BKB Group adequate to facilitate all residents? & 1 & 9 \\
\hline Are the numbers of BKB cadres representative enough? & 2 & 8 \\
\hline Has a structural management formed in the BKB? & 0 & 10 \\
\hline Are the counseling materials compiled and scheduled? & 5 & 5 \\
\hline Do cadres feel qualified to deliver counseling materials in every BKB activity? & 2 & 8 \\
\hline Are the materials in BKB always delivered by a team of experts? & 2 & 8 \\
\hline Are BKB activities well-documented? & & 1 \\
\hline Are all families with toddlers members of BKB? & & 10 \\
\hline Do all BKB members always participate in BKB Activities? & 2 & 8 \\
\hline Are materials for BKB activities compiled and scheduled in one year? & 2 & 2 \\
\hline
\end{tabular}

From the data displayed above, it was found that not all people, especially families with children, had access to $\mathrm{BKB}$, as it was shown by the fact that not all RW had BKB. In addition, the existing data of a village with $\mathrm{BKB}$, it was known that Dusun Citimun only had one group. Hence, not all residents could be facilitated, not to mention the small number of BKB cadres.

Meanwhile, institutionally, the BKB in Dusun Citimun had not yet been administratively organized, as this was indicated by the absence of a structural management, the counselling materials had not yet been compiled and scheduled well, and BKB activities had not been well documented. Hence, it would be difficult to evaluate every activity that had been carried out.

From the perspective of human resources, cadres with an average education level up to high school did not feel confident enough to provide counselling for the community regarding themes that specifically require certain expertise, take nutrition for instance, which is ideally conveyed by people with competence (Interview on August 2, 2019 with BKB Cadres).

The repercussions of substandard management of BKB in addition to the limited number of BKB group, which consisted only of one group in one village, came in form of people's reluctance to participate in BKB activities (Interview on 3 August 2019). This was suggested by the data that indicated from the total 132 families with toddlers, only 68 families $(41.47 \%)$ were registered as BKB members, and among 68 families who were registered as BKB members, only 32 families (24.24\%) participated in BKB activities. This also hinted the lack of citizen participation in BKB activities.

\section{Pre-action evaluation results}

Based on several stages undertaken in the identification activities, several findings were obtained:

1. There was no counselling activity that specifically informed the community about stunting. As a result, people's insight about stunting was very limited. This was also confirmed by the data that indicated the stunting rate in Dusun I Citimun village reached up to $41 \%$ for the category of $0-1$ year of age.

2. $\mathrm{BKB}$ as the designated medium of education for the community, due to the limited capacity in Dusun I Citimun and the cadres' limited capability, failed to provide comprehensive access to BKB activities. Therefore, a great portion of information was not informed to the community.

3. Poor management in BKB activities

These findings serve as the basis for the team to design materials and actions to be assigned to the residents of Dusun Citimun. The designed action plan comprises as follows:

1. Providing education for the residents of Dusun Citimun regarding stunting through seminars and campaigns on stunting through posters in every BKB activity post.

2. Forming a BKB group in every RW in Dusun I Citimun.

3. Organizing a coaching clinic for cadres in administering BKB activities.

The findings and action plan to be delivered were later socialized to related parties, especially to the head of the village and cadres in the Kampung KB and generally to the community. From this consolidation activity, several inputs were pointed out for the implementation of research activities including:

1. The materials to be delivered needed to be compiled in form of a module.

2. Resource persons involved in this study consisted of academics, namely team members of this study and practitioners from the public health center.

3. Every RW had to send a delegation to become a cadre in BKB activities.

\subsection{Action Stage}

This was the stage of implementing the actions designed 
previously, which was classified into two activities. The first was counselling activity intended for the community about stunting prevention efforts, and the second was BKB management assistance to $\mathrm{BKB}$ cadres, serving as socialization and education media for the community about stunting prevention.

\subsubsection{Counselling or Education Materials}

Referring to the findings in the pre-action evaluation regarding the community's limited insight about stunting and the high rate of stunting cases in Dusun I Citimun, the materials presented in the counselling focused on the efforts to prevent stunting by providing insight concerning good nutritional intake for children. This was based on the fact that stunting or stunted body growth is a form of malnutrition characterized by height-for-age below the standard deviation $(<-2 \mathrm{SD})$ [53]. Stunting is a long-term reflection of insufficient quality and quantity of nutrition and frequent infections during childhood [54]. Accordingly, the materials given to the participants were related to encouraging exclusive breastfeeding campaign, tips on making quality but economical complementary feeding because children who are stunted are essentially the outcome of chronic nutritional problems as the result poor quality food, complemented with morbidity, infectious diseases, and environmental issues [55].

In the materials of this study, participants were also given insights into indicators of stunted child growth. Childhood stunting is associated with delays in motor development and lower levels of intelligence [56] and the fallouts caused by stunting in children include depression of immune function, metabolic changes, subsided motor development, low cognitive level and low academic scores. Children who suffer from stunting will grow into adults who are at risk of obesity, glucose tolerance, coronary heart disease, hypertension, osteoporosis, declining performance and productivity [57].

Considering the participants characters as part of religious society based on Islamic values, an attempt to strengthen the materials using Islamic religious values were delivered to the participants. Collaboration was made with academics who were competent in the field of Islam in providing materials related to parenting, exclusive breastfeeding and nutritional intake for toddlers according to Islamic perspective. A religious touch is important in terms of educating the people because religion is the most powerful force in influencing one's actions [58]-[60]. In fact, religion is a pivotal social force with a powerful influence on the social environment [61].

\subsubsection{Materials for Cadre Assistance}

Other than being presented to the general public, the materials above were also delivered to designated cadres in every RW in Dusun Citimun, particularly cadres in Dusun I. This was done as an attempt to upgrade cadres' capability in providing counselling for the community during BKB activities, as well as training ambassadors for stunting prevention in every RW, so that this activity is not only incidental but also sustainable.

Beyond materials on stunting prevention, cadres were trained to administer BKB activities including collecting data of families with toddlers and pregnant women, scheduling BKB activities, compiling guided BKB activity materials, and training on filling out Growth Chart (KMS, Kartu Menuju Sehat). Hence, the cadres have management skills in organizing BKB activities as a medium of education for the community.

\subsection{Review Stage}

Right after the participants and cadres had received the materials, the follow-up materials given to the participants and cadres through monitoring was reviewed. Participants were given a monitoring card containing the schedule for feeding the babies and the food menu as a form of nutrition intake intervention. The cadres were reviewed regarding data collection on families with babies, BKB membership, and the implementation of BKB activities in every RW as well as providing assistance in preparing materials for BKB activities. These were done as efforts to review the extent of mastery over the given materials.

\subsection{Evaluation Stage}

The final stage of this study was intended to review the success rate of the team in encouraging the community's active participation in BKB as an attempt to prevent stunting. The evaluated items included participants' insights about stunting, and the amount of community participation in BKB activities. The results of post-action evaluation activities are as follows: 


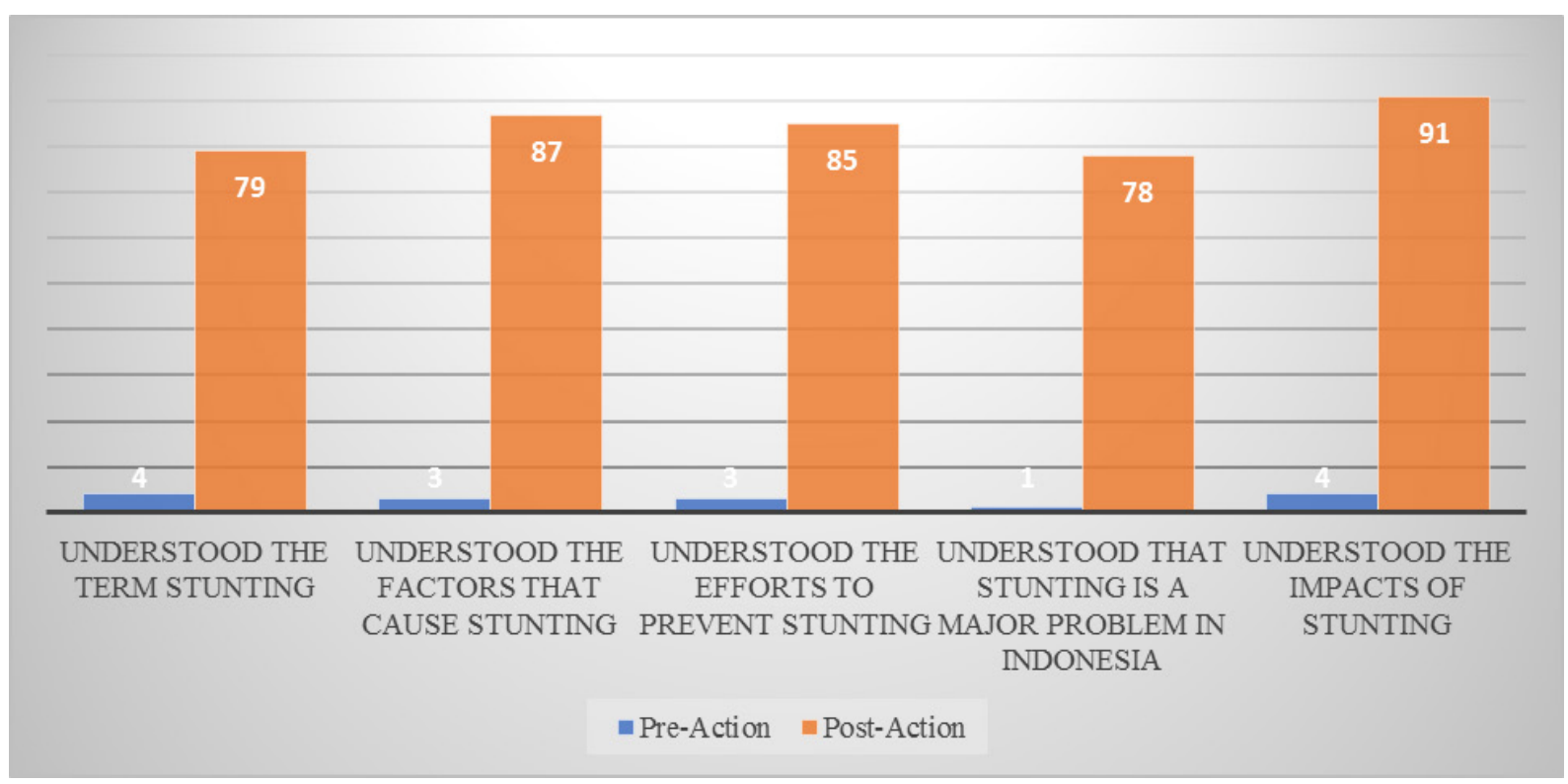

Figure 3. Improvement of Community's Insights on Stunting

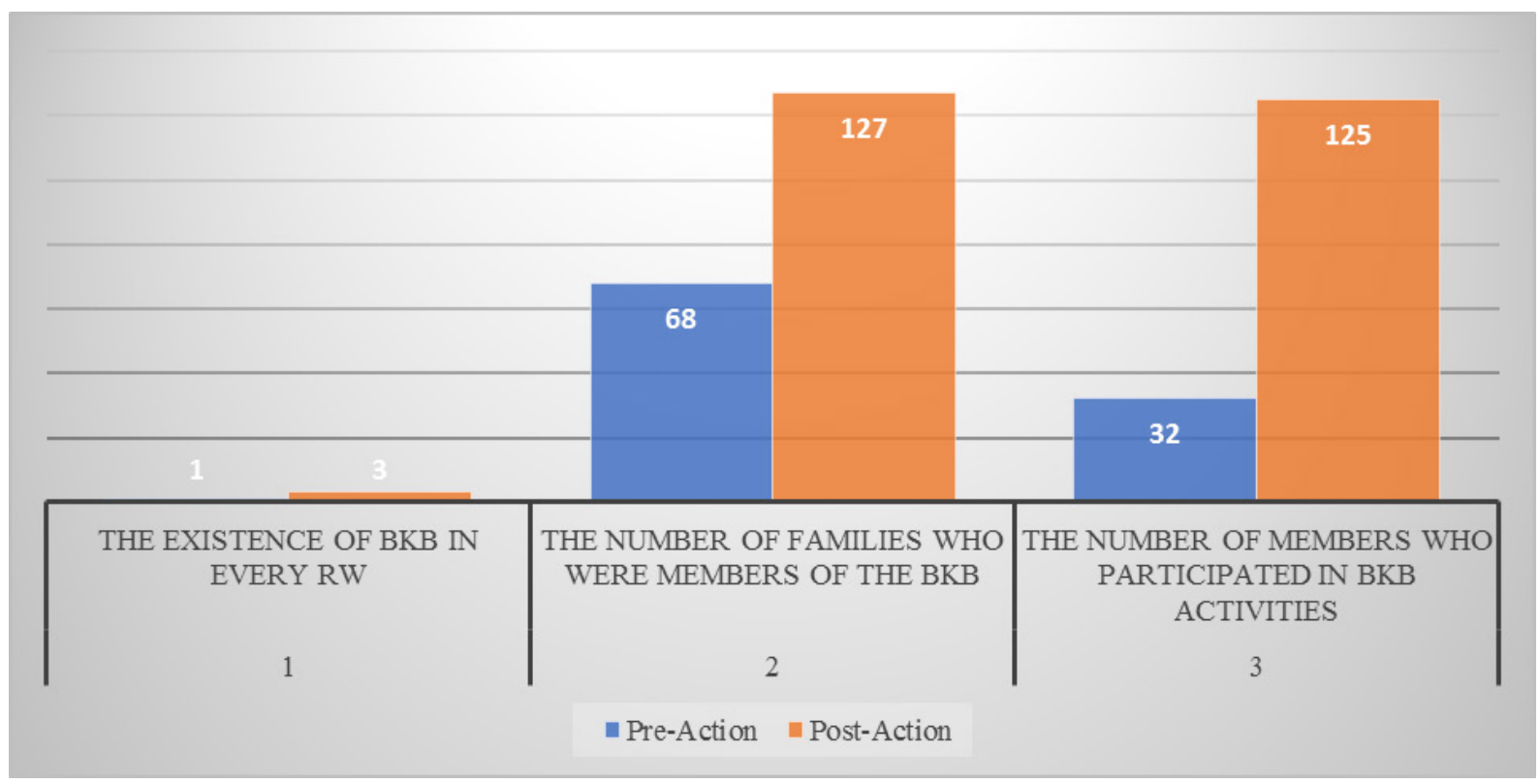

Figure 4. Improvement of Community's Participation in BKB

\subsubsection{Community's Insights regarding Stunting}

According to the Figure 3, it can be inferred that there was an increase in the community's insights regarding stunting before and after getting the materials. The acknowledgement of the term stunting boosted by $75 \%$, of the factors that caused stunting boosted by $85 \%$, of the efforts to prevent stunting boosted by $82 \%$, of stunting being a major problem and becoming a program of the Indonesian government boosted by $77 \%$, and of the impacts caused by stunting boosted by $87 \%$.

\subsubsection{The Rate of Community Participation in BKB}

Based on the Figure 4. , it can be inferred that there was an increase in the role of $\mathrm{BKB}$ in the community as a medium of education and an increase in the number of community participation in BKB activities. The number of BKB that initially only consisted of one group in Dusun I Citimun, then grew into two groups. The initial number of BKB members grew from 68 families into 127 families and the number of members who actively participate in BKB activities grew from 32 families into 125 families.

The facts above present a proof that the high rate of stunting cases in an area is likely to arise due to the lack of awareness and insights regarding stunting problems. Education and the role of mothers play an instrumental role in efforts to prevent stunting in addition to direct intervention from related parties [26], [32]. Other than health problems, stunting is also a social problem because 
it involves the next generation that determines the nation's future. It is impossible for a nation to move forward if the cognitive, motoric, and socio-emotional developments of its citizens are hampered by stunting [23]. Attempts to tackle social issues must be initiated by changing ways of thinking [62], and changes in thinking can only be passed through the door of education [63].

In addition to increase families' understanding on stunting and its prevention, effective interventions are needed to cut down stunting rate, micronutrient deficiencies, and child mortality. If applied on a sufficient scale, it would reduce (all child deaths) by about a quarter in the short term [64]. Other interventions carried out to counter stunting focuses on immunization, intensified exclusive breastfeeding and access to nutrient-rich food among adopted children along their families through community-based nutrition interventions [65]. These interventions can be carried out through strategies such as education and counselling on nutrition, dietary supplements in areas with food insecurity that can substantially reduce stunting and disease-related issues, particularly interventions for maternal nutrition that potentially reduce the risk of low birth weight by $16 \%$ [64].

These interventions can run well if related parties, both the government as policy makers and the community, actively participate and collaborate in terms of promoting stunting prevention campaign. This is important because one of the efforts to accelerate stunting reduction in Southeast Asia is to increase the availability and access to nutritious food through collaboration between private and public sectors. The Association of Southeast Asian Nations (ASEAN) can play the role as a facilitator. The private sector can produce and market nutritious food, while the public sector sets standards, promotes healthy and nutritious food, and ensures access to nutritious food for the poor areas, for example through social safety net programs [66]. This indicates that interventions are carried out in both the health and non-health sectors involving various levels of society such as government, private sectors, civil society [64].

\section{Conclusion}

From the elucidation above, it can be concluded that there are steps that must be undertaken as efforts to encourage community's participation to prevent stunting. Through observation, these steps narrow down into a model of research activities called I-CARE, which is an abbreviation for Identification, Consolidation, Action, Review, and Evaluation. This I-CARE model was proven to have increased the public's insight and understanding regarding stunting prevention. Understanding on stunting boosted up to $75 \%$, understanding the factors that cause stunting boosted up to $85 \%$, the insights of efforts to prevent stunting boosted up to $82 \%$, awareness of stunting as a major problem and becoming a program of the Indonesian government that needs to collective efforts boosted up to $77 \%$ and the insight of the impacts caused by stunting boosted up to $87 \%$. Therefore, one of the attempts to perform in efforts to prevent stunting is to improve the public's understanding of stunting through education. In addition, I-CARE model is an effort that can be implemented by related parties. Apart from that, I-CARE also bears caring values and a jargon that needs to be instilled in every academic community. Hence, it can always build a caring attitude towards the problems encountered by society, considering that the academic community essentially has a role as the agent of change.

\section{REFERENCES}

[1] W. W. UNICEF, "Levels and trends in child malnutrition: $\mathrm{UNICEF/WHO/The} \mathrm{World} \mathrm{Bank} \mathrm{joint} \mathrm{child} \mathrm{malnutrition}$ estimates," UNICEF New York, NY, USA, 2012.

[2] R. D. Shiwakoti, M. D. Devkota, and R. Paudel, "Women's empowerment and nutritional status of their children: A community - based study from villages of Bhaktapur District, Nepal," Universal Journal of Public Health, vol. 5, no. 1, pp. 8-16, 2017. DOI: 10.13189/ujph.2017.050102

[3] A. J. Prendergast and J. H. Humphrey, "The stunting syndrome in developing countries," Paediatr. Int. Child Health, vol. 34, no. 4, pp. 250-265, 2014.

[4] X. Wang, B. Höjer, S. Guo, S. Luo, W. Zhou, and Y. Wang, "Stunting and 'overweight' in the WHO Child Growth Standards--malnutrition among children in a poor area of China," Public Health Nutr., vol. 12, no. 11, pp. 1991-1998, 2009.

[5] K. G. Dewey and K. Begum, "Long-term consequences of stunting in early life," Matern. Child Nutr., vol. 7, pp. 5-18, 2011.

[6] M. De Onis et al., "Comparison of the World Health Organization (WHO) Child Growth Standards and the National Center for Health Statistics/WHO international growth reference: implications for child health programmes," Public Health Nutr., vol. 9, no. 7, pp. 942-947, 2006.

[7] T. Beal, A. Tumilowicz, A. Sutrisna, D. Izwardy, and L. M. Neufeld, "A review of child stunting determinants in Indonesia," Matern. Child Nutr., vol. 14, no. 4, p. e12617, 2018.

[8] A. Azriful, E. Bujawati, H. Habibi, S. Aeni, and Y. Yusdarif, "Determinan Kejadian Stunting Pada Balita Usia 24-59 Bulan di Kelurahan Rangas Kecamatan Banggae Kabupaten Majene," Al-sihah Public Heal. Sci. J., vol. 10, no. 2, 2018.

[9] D. Susilawaty, "WHO: 7,8 Juta Balita di Indonesia Penderita Stunting | Republika Online,” 2018. https://www.republika. co.id/berita/nasional/umum/18/01/24/p30s85396-who-78-ju ta-balita-di-indonesia-penderita-stunting (accessed Jan. 04, 2021).

[10] M. Verawati, "Analisis Permasalahan Stunting Pada Balita 
Di Indonesia," in 1st Prosiding Seminar Nasional Fakultas Ilmu Kesehatan, 2019, pp. 62-64.

[11] V. D. Putri, "Praktik Pengasuhan Anak Pada Keluarga Petani Peserta Bina Keluarga Balita (BKB) Melati 3 Di Desa Nguken Kecamatan Padangan Kabupaten Bojonegoro," Indones. J. Early Child. Educ. Stud., vol. 1, no. 2, 2012.

[12] S. Setianingrum, L. Desmawati, and A. Yusuf, "Peranan Kader Bina Keluarga Balita dalam Optimalisasi Tumbuh Kembang Fisik Motorik Anak Usia Dini," J. Nonform. Educ. Community Empower., vol. 1, no. 2, pp. 137-145, 2017.

[13] N. P. Ariesta, "Peran kader bina keluarga balita dalam upaya pembinaan kesejahteraan keluarga melalui layanan bina keluarga balita (studi deskriptif di bkb kasih ibu i kelurahan bulukerto kecamatan bulukerto kabupaten wonogiri)." Universitas Negeri Semarang, 2011.

[14] M. De Onis, M. Blössner, and E. Borghi, "Prevalence and trends of stunting among pre-school children, 1990-2020," Public Health Nutr., vol. 15, no. 1, pp. 142-148, 2012.

[15] G. Yasmin, L. Kustiyah, and C. M. Dwiriani, "Risk factors of stunting among school-aged children from eight provinces in Indonesia," Pakistan J. Nutr., vol. 13, no. 10, p. $557,2014$.

[16] N. K. Aryastami, A. Shankar, N. Kusumawardani, B. Besral, A. B. Jahari, and E. Achadi, "Low birth weight was the most dominant predictor associated with stunting among children aged 12-23 months in Indonesia," BMC Nutr., vol. 3, no. 1, pp. 1-6, 2017, doi: 10.1186/s40795-017-0130-x.

[17] D. J. P. Barker and P. M. Clark, "Fetal undernutrition and disease in later life," Rev. Reprod., vol. 2, no. 2, pp. 105-112, 1997.

[18] G. Apriluana and S. Fikawati, "Analisis Faktor-Faktor Risiko terhadap Kejadian Stunting pada Balita (0-59 Bulan) di Negara Berkembang dan Asia Tenggara," Media Penelit. dan Pengemb. Kesehat., vol. 28, no. 4, pp. 247-256, 2018.

[19] I. Budiastutik and M. Z. Rahfiludin, "Faktor Risiko Stunting pada anak di Negara Berkembang," Amerta Nutr., vol. 3, no. 3, pp. 122-129, 2019.

[20] D. Izwardy, "Studi Status Gizi Balita Terintegrasi Susenas 2019,” Jakarta Kemenkes RI, 2020.

[21] M. De Onis and F. Branca, "Childhood stunting: a global perspective," Matern. Child Nutr., vol. 12, pp. 12-26, 2016.

[22] D. J. Millward, "Nutrition, infection and stunting: the roles of deficiencies of individual nutrients and foods, and of inflammation, as determinants of reduced linear growth of children," Nutr. Res. Rev., vol. 30, no. 1, p. 50, 2017.

[23] S. Grantham-McGregor et al., "Developmental potential in the first 5 years for children in developing countries," Lancet, vol. 369, no. 9555, pp. 60-70, 2007.

[24] D. L. Pelletier, E. A. Frongillo Jr, and J.-P. Habicht, "Epidemiologic evidence for a potentiating effect of malnutrition on child mortality.," Am. J. Public Health, vol. 83, no. 8, pp. 1130-1133, 1993.

[25] D. L. Pelletier and E. A. Frongillo, "Changes in child survival are strongly associated with changes in malnutrition in developing countries," J. Nutr., vol. 133, no. 1, pp. 107119,2003
[26] R. D. Semba, S. de Pee, K. Sun, M. Sari, N. Akhter, and M. W. Bloem, "Effect of parental formal education on risk of child stunting in Indonesia and Bangladesh: a cross-sectional study," Lancet, vol. 371, no. 9609, pp. 322-328, 2008.

[27] R. Martorell, L. K. Khan, and D. G. Schroeder, "Reversibility of stunting: epidemiological findings in children from developing countries.," Eur. J. Clin. Nutr., vol. 48, pp. S45-57, 1994.

[28] G. B. Spurr, M. Barac-Nieto, and M. G. Maksud, "Productivity and maximal oxygen consumption in sugar cane cutters," Am. J. Clin. Nutr., vol. 30, no. 3, pp. 316-321, 1977.

[29] E. Royston, S. Armstrong, and W. H. Organization, Preventing maternal deaths. World Health Organization, 1989.

[30] J.-P. Habicht, C. Yarbrough, A. Lechtig, and R. E. Klein, "Relationship of birthweight, maternal nutrition and infant mortality.," Nutr. Rep. Int., vol. 7, no. 5, p. 533, 1973.

[31] R. Martorell, H. L. Delgado, H. Delgado, V. Valverde, and R. E. Klein, "Maternal stature, fertility and infant mortality," Hum. Biol., pp. 303-312, 1981.

[32] M. H. Emamian, M. Fateh, N. Gorgani, and A. Fotouhi, "Mother's education is the most important factor in socio-economic inequality of child stunting in Iran," Public Health Nutr., vol. 17, no. 9, pp. 2010-2015, 2014.

[33] L. G. Pradnyawati and K. A. Sanjaya, "Pemberdayaan Kader Bina Keluarga Balita Dalam Pencegahan Stunting Dan Akselerasi Taraf Ekonomi Di Desa Bresela, Kecamatan Payangan Gianyar," J. Apl. dan Inov. Iptek, vol. 2, no. 1, pp. $37-45,2020$

[34] K. Ayunurahmawati, "PENCEGAHAN CHILDREN STUNTING MELALUI PROGRAM BINA KELUARGA BALITA (BKB)(Studi Program Dinas Pengendalian Penduduk Dan Keluarga Berencana (DPPKB) Di Desa Wonoayu Kecamatan Wajak Kabupaten Malang)." University of Muhammadiyah Malang, 2019.

[35] F. Tentama, H. D. L. Delfores, A. E. Wicaksono, and S. F. Fatonah, "Penguatan Keluarga Sebagai Upaya Menekan Angka Stunting dalam Program Kependudukan, Keluarga Berencana dan Pembangunan Keluarga (KKBPK)," $J$. Pemberdaya. Publ. Has. Pengabdi. Kpd. Masy., vol. 2, no. 1, p. 113,2018

[36] N. S. Yunas and F. D. Nailufar, "Collaborative Governance melalui Program Kampung KB Di Kabupaten Jombang," CosmoGov J. Ilmu Pemerintah., vol. 5, no. 2, pp. 162-173, 2019.

[37] D. A. Ningsih, F. Firdawati, and P. H. Satria, "Awarding Support Becomes a Dominant Factor in the Election of Family Planning in the Long-Term Contraception Method in Kampung KB," J. Aisyah J. Ilmu Kesehat., vol. 4, no. 1, pp. 73-81, 2019.

[38] Y. W. Migang, "Specific Nutrition Interventions and Sensitive Nutrition Interventions with Baduta Nutrition Status in Kampung KB as an Effort to Deal with Demographic Bonuses," KEMAS J. Kesehat. Masy., vol. 16, no. 1 , p. 14,2020 .

[39] A. Handayani, S. N. Ardini, and P. D. Yulianti, "THE EVALUATION STUDIES OF KAMPUNG KB IN 
CENTRAL JAVA,” J. Kesejaht. Kel. dan Pendidik., vol. 7, no. 01, pp. 63-73, 2020.

[40] R. S. Darwis, "Membangun Desain Dan Model Action Research Dalam Studi Dan Aksi Pemberdayaan Masyarakat," KOMUNIKA, vol. 10, no. 1, pp. 142-153, 2016.

[41] J. W. Creswell, "Education research; planning, conducting, evaluating, quantitafive and qualitatifive research." United states of America, Pearson Education, inc, 2012.

[42] J. W. Creswell, Educational research: Planning, conducting, and evaluating quantitative. Prentice Hall Upper Saddle River, NJ, 2002.

[43] K. Messiou, "Collaborative action research: facilitating inclusion in schools," Educ. Action Res., vol. 27, no. 2, pp. 1-13, 2019, doi: 10.1080/09650792.2018.1436081.

[44] L. K. Zech, C. L. Gause-Vega, M. H. Bray, T. Secules, and S. R. Goldman, "Content-Based Collaborative Inquiry: A Professional Development Model for Sustaining Educational Reform," Educ. Psychol., vol. 35, no. 3, pp. 207-217, 2000, doi: 10.1207/S15326985EP3503_6.

[45] D. Heil, "The internet and student research: Teaching critical evaluation skills," Teach. Libr., vol. 33, no. 2, p. 26, 2005.

[46] I. E. Allen and C. A. Seaman, "Likert scales and data analyses," Qual. Prog., vol. 40, no. 7, pp. 64-65, 2007.

[47] W. Widhiarso, "Skalo program analisis skala Guttman," Yogyakarta, Indones. Univ. Gajah Mada, 2011.

[48] T. J. Brigham, "Taking advantage of Google's Web-based applications and services," Med. Ref. Serv. Q., vol. 33, no. 2, pp. 202-210, 2014, doi: 10.1080/02763869.2014.897521.

[49] C.-H. Chiu, H.-W. Cheng, and C.-Y. Wu, "Applying questioning or reading strategy to review technology enhanced coedited notes of elementary school students," $J$. Educ. Res., vol. 109, no. 2, pp. 111-121, 2016, doi: $10.1080 / 00220671.2014 .924471$.

[50] Y.-T. Lin, C.-H. Chang, H.-T. Hou, and K.-C. Wu, "Exploring the effects of employing Google Docs in collaborative concept mapping on achievement, concept representation, and attitudes," Interact. Learn. Environ., vol. 24, no. 7, pp. 1552-1573, 2016, doi: 10.1080/10494820.2015.1041398.

[51] L. Travis, "One of many free survey tools: Google docs," $J$. Electron. Resour. Med. Libr., vol. 7, no. 2, pp. 105-114, 2010, doi: 10.1080/15424065.2010.482902.

[52] D. Susilawaty/, "WHO: 7,8 Juta Balita di Indonesia Penderita Stunting," Republika, Jakarta, Jan. 2018.

[53] E. Kusumawati, S. Rahardjo, and H. P. Sari, "Model pengendalian faktor risiko stunting pada anak bawah tiga tahun," Kesmas Natl. Public Heal. J., vol. 9, no. 3, pp. 249 $256,2015$.
[54] R. Shrimpton, C. G. Victora, M. de Onis, R. C. Lima, M. Blössner, and G. Clugston, "Worldwide timing of growth faltering: implications for nutritional interventions," Pediatrics, vol. 107, no. 5, pp. e75--e75, 2001.

[55] R. D. Semba, S. de Pee, K. Sun, M. Sari, N. Akhter, and M. W. Bloem, "Effect of parental formal education on risk of child stunting in Indonesia and Bangladesh: a cross-sectional study," Lancet, vol. 371, no. 9609, pp. 322-328, 2008.

[56] B. T. Crookston et al., "Children who recover from early stunting and children who are not stunted demonstrate similar levels of cognition, 2," J. Nutr., vol. 140, no. 11, pp. 1996-2001, 2010.

[57] G. C. Mandal, K. Bose, S. Bisai, and S. Ganguli, "Undernutrition among Integrated Child Development Services (ICDS) Scheme Children aged 2-6 years of Arambag, Hooghly District, West Bengal, India: A serious public health problem," Ital. J. Public Health, vol. 5, no. 1, 2012.

[58] F. Fridayanti, "Religiusitas, Spiritualitas Dalam Kajian Psikologi dan Urgensi Perumusan Religiusitas Islam," Psympathic J. Ilm. Psikol., vol. 2, no. 2, pp. 199-208, 2015.

[59] T. Muhtar, T. Supriyadi, A. S. Lengkana, and S. Hanifah, "Religious Characters-Based Physical Education Learning in Elementary School," Int. J. Learn. Teach. Educ. Res., vol. 18 , no. $12,2020$.

[60] T. Supriyadi, J. Julia, and E. Firdaus, "The Problems of Gender Equality: A Reconstruction of Islamic Doctrine," $J$. Soc. Stud. Educ. Res., vol. 10, no. 2, pp. 91-110, 2019.

[61] R. A. Emmons and R. F. Paloutzian, "The psychology of religion," Annu. Rev. Psychol., vol. 54, no. 1, pp. 377-402, 2003.

[62] J. Rakhmat, "Rekayasa Sosial," Bandung: Remaja Rosdakarya, 2005.

[63] A. Takashima and H. Matsuo, "The effect of an education program on Japanese nurses' attitudes towards foreign patients," Universal Journal of Public Health, vol. 5, no. 1, pp. 54-61, 2017. DOI: 10.13189/ujph.2017.050108

[64] M. Mitra, "Permasalahan Anak Pendek (Stunting) dan Intervensi untuk Mencegah Terjadinya Stunting (Suatu Kajian Kepustakaan)," J. Kesehat. Komunitas, vol. 2, no. 6, pp. 254-261, 2015.

[65] E. Bloss, F. Wainaina, and R. C. Bailey, "Prevalence and predictors of underweight, stunting, and wasting among children aged 5 and under in western Kenya," J. Trop. Pediatr., vol. 50, no. 5, pp. 260-270, 2004.

[66] M. W. Bloem et al., "Key strategies to further reduce stunting in Southeast Asia: Lessons from the ASEAN countries workshop," Food Nutr. Bull., vol. 34, no. 2_suppl1, pp. S8-S16, 2013 